\title{
ANÁLISE DE TRADUCIÓN/AUTOTRADUCIÓN: MULLER NO BAÑO (MANUEL RIVAS)
}

\author{
Sandra López Salceda, Natalia Moreiras Arias, Paloma M. Pérez Feijoo, \\ Lucía Rouco Paz, Antonio Santalla Fernández
}

\begin{abstract}
The following study was conceived to prompt a debate between translation and self-translation. This has been done through the analysis of the book Muller no baño by Manuel Rivas, examining the different linguistic features (lexical, grammatical, and cultural) determining the quality of a good translation. Similarly, the paper focuses on the interferences and cultural problems that arise when working with two languages in contact (Galician and Spanish, in this particular case).

Keywords: translation; self-translation; languages in contact; linguistic features.

Resumo: O presente estudo foi deseñado para abrir un debate entre a tradución e a autotradución tomando como obxecto de análise a obra Muller no baño de Manuel Rivas e examinando os diferentes rasgos lingüísticos (lexicais, gramaticais e culturais) que determinan a calidade dunha boa tradución. Do mesmo xeito, este artigo céntrase nas interferencias e problemas culturais que xorden cando se traballa entre dúas linguas en contacto (galego e español, neste caso).

Palabras chave: tradución; autotradución; linguas en contacto; rasgos lingüísticos.
\end{abstract}

\section{Introdución}

O presente traballo busca realizar unha análise crítica das vantaxes e desvantaxes da autotradución fronte á tradución, é dicir, as consecuencias, positivas ou negativas, de que un escritor sexa tamén o tradutor da súa propia obra. Para isto, analizaremos todos os aspectos da linguaxe que poden resultar conflitivos á hora do proceso tradutolóxico.

O autor crea, ao seu antollo, unha realidade única dándolle o rexistro, a forma, o tema e o punto de vista que desexa, mentres que o tradutor é un «recreador» que debe limitarse a reproducir noutra lingua todas as características da obra orixinal, axustándose a unhas esixencias moito maiores que o autor, xa que debe ser quen de reproducir fielmente a obra orixinal aportándolle a mesma calidade.

Porén, observamos unha diferenza palpable cando falamos de autotradución, pois o autor é o tradutor da súa propia obra e as limitacións á hora do proceso tradutolóxico redúcense mesmo ata desapareceren, de xeito que podemos atopar frecuentemente obras autotraducidas que introducen modificacións con respecto ao orixinal, pois neste caso o tradutor non debe fidelidade a ninguén máis cá el mesmo. Esta práctica non se trata 
dun caso illado nin actual, senón que é un fenómeno que se vén realizando xa dende o Rexurdimento e da man de autores da importancia de Rosalía de Castro ou Curros Enríquez (Dasilva 2009: 144). Isto permítelles sortear as ambigüidades ou falsos sentidos, evitar interpretacións erróneas, corrixir os erros cometidos na primeira versión do texto e mesmo asegurar que o receptor da tradución recibirá un texto equivalente ao que recibiron os receptores do texto orixinal. Mais non sempre se dá esta condición: é moi frecuente que os autotradutores introduzan cambios nas súas obras traducidas, afastándose das orixinais, o que supón a principal desvantaxe da autotradución, xa que elimina a equivalencia da tradución con respecto ao orixinal. Son modificacións que poden convertérense mesmo en ousadías cando permiten sortear o destino dos personaxes das devanditas obras e chegar a revivir algún deles nesas novas versións, como fixera Suso de Toro en Ambulancia (Dasilva 2009: 145).

Malia que o autor é o «lector ideal» da súa obra e aínda que domine tanto a lingua de partida como a de chegada, pode non contar cos coñecementos propios dun tradutor profesional para solucionar as dificultades que presentan as diferenzas entre dúas linguas e culturas. E non só iso: en moitos casos, o autor está tan apegado á súa obra que non é quen de lle atopar os defectos ou, o que é o mesmo, non afronta a tradución con obxectividade. Tamén pode ser que, por descoñecemento do proceso real de tradución e pola proximidade das linguas, os autores caian en erros que fagan que a tradución non resulte idiomática, ben porque as estruturas dunha lingua non se empregan na outra ou mesmo porque, como lle ocorría a Cunqueiro, o medo a caer nas interferencias lingüísticas leva a aplicar unha ultracorrección que evidencia, paradoxalmente, os problemas resultantes desas interferencias que se tentaban evitar (Rodríguez Vega 1999: 1357-1358). Por estes motivos, e cada vez con máis frecuencia, escritores que anteriormente exercían tamén de autotradutores agora decántanse pola colaboración cun tradutor profesional, o que aporta maior obxectividade á tradución, sen esquecer a maior calidade da que gozará o texto traducido. Este é o caso de Manuel Rivas, que ten autotraducido moitas das súas obras mais hoxe en día colabora activamente no proceso de tradución levado a cabo pola súa tradutora, Dolores Vilavedra.

\section{Descrición do corpus e da análise}

O corpus utilizado para exemplificar as características xerais e concretas das autotraducións do autor é a obra de Manuel Rivas ${ }^{1}$ Muller no baño, publicada en 2002 pola Editorial Xerais, que contén 266 páxinas, así como a tradución desta obra realizada polo propio autor, co nome de Mujer en el baño, publicada en 2003 pola Editorial Alfaguara, con 312 páxinas. Trátase dunha obra que consta dunha selección de artigos xornalísticos que forman parte da publicación española El País Semanal e que non é fácil adscribir a un xénero determinado, xa que tanto se pode considerar un ensaio que acaba por converterse en ficción como unha obra de ficción que se achega á realidade en forma de crítica social, no sentido de que plasma en gran medida cuestións da problemática contemporánea. O autor afronta estas cuestións facendo unha reflexión crítica e irónica sobre a situación

\footnotetext{
Manuel Rivas é un dos autores galegos con maior presenza nacional e internacional e as súas obras insírense en diversos xéneros (narrativa, poesía, artígos xornalísticos, ensaios literarios...). Parte da súa produción, orixinalmente escrita en galego, foi traducida a outras linguas, coma o español (onde fixo algunhas autotraducións), o inglés, o alemán, o grego, o turco ou o xaponés. Destaca por un modo de escribir único e característico, onde fai un uso peculiar da lingua, o que fai que algúns críticos o sitúen no estilo do realismo máxico galego.
} 
da muller no mundo e sobre os aspectos da vida actual que el mesmo cualifica como «politicamente canalla», utilizando a ironía e o humor para loitar contra o cinismo e a indiferenza.

O enfoque co que se abordaron os distintos aspectos que foron obxecto desde traballo consistiu nunha lectura intensiva do conxunto do texto na procura dos elementos referidos para a súa posterior análise, que se fixo capítulo a capítulo, comparando as dúas versións e anotando, nese proceso, as cousas relevantes relacionadas con cada apartado. Deste xeito, consideráronse desde as unidades mínimas de tradución ata segmentos textuais maiores, incluído o conxunto do texto como unidade coherente. A continuación, e para rematar, procedeuse a contextualizar as particularidades de ditos aspectos, coa correspondente exemplificación exhaustiva de cada un dos elementos atopados.

Queremos indicar tamén que, ao citarmos exemplos da obra Muller no baño (Mujer en el baño), poremos entre corchetes os números das páxinas nas que se atopan, sendo o primeiro o da versión galega e o segundo a da castelá, se non se indica o contrario, para facilitar así a súa localización.

\section{Aspectos morfosintácticos}

O campo da morfosintaxe adoita ser conflitivo para os falantes bilingües de galego e castelán, xa que son frecuentes as interferencias no uso dos tempos verbais, no diferente xénero de certas palabras en ambas as dúas linguas, ou na colocación dos pronomes, por citar algúns dos aspectos máis problemáticos. A continuación, pasaremos a considerar por extenso as confusións e os erros máis frecuentes e a identificar a súa presenza ou ausencia no texto analizado.

\section{Substantivo e adxectivo}

No tocante á forma dos substantivos e adxectivos, non adoitan aparecer serios problemas. Deixando para máis adiante a escolla do léxico e os problemas xerados polo xénero e número dalgunhas palabras en castelán e galego, aquí mencionaremos unicamente os problemas que xorden co sufixo diminutivo -iño á hora de o transvasar ao castelán, xa que frecuentemente a lingua galega aporta unha maior connotación ás palabras a través dos sufixos, como é o caso deste problemático diminutivo, que leva unha grande carga de afecto cara á persoa ou ao obxecto ao que se aplica.

Aínda que non é o caso da obra analizada, moitos autotradutores galegos atopan serios problemas para reproduciren a mesma connotación en español polo que, nalgúns casos, como explica Luisa Blanco Rodríguez (1988: 175-176) referíndose a Álvaro Cunqueiro, acaban por decidir manter este sufixo, conscientes de que o lector castelán saberá apreciar a súa orixe galega e o seu significado.

No caso dos adxectivos, podemos atopar erros na formación do grao comparativo. O máis común é a confusión das partículas comparativas como e coma nas comparativas de igualdade; e que, ca e do que nas de superioridade, que se reflicte no uso erróneo de como e que seguidos de pronomes e de coma e ca seguidos de verbos, únicos casos nos que non son válidas todas as opcións anteriores, e da contracción de ca coa preposición a, estea soa ou contraída co artigo determinado. Porén, insistimos en que non se atopou ningún erro deste tipo na obra analizada:

«Se un adulto quere quedar coma un parvo de vez» [141]

«Si un adulto quiere quedar como un gilipollas» [208] 


\section{Verbo}

A utilización das formas verbais castelás é un dos aspectos máis conflitivos para os falantes galegos e, en menor medida, as formas verbais galegas para falantes casteláns. Especialmente, os tempos compostos do castelán supoñen unha enorme dificultade para os galegos, sexan galegofalantes ou non, así como o uso das perífrases (onde se atopan multitude de interferencias en ambos os dous sentidos). De novo, non se atopan erros na obra referentes á utilización dos tempos verbais ou das perífrases:

«coñecín un rapaz galego que conseguira un emprego» [142]

«conocí a un joven gallego que había conseguido un empleo» [210]

«Nun congreso de filósofos chegouse á conclusión» [128]

«En un congreso de filósofos se ha llegado a la conclusión» [229]

«O segundo mito viría ser o da identificación» [149]

«El segundo mito vendría a ser el de la identificación» [215]

\section{Determinante}

Os determinantes non adoitan supoñer un problema para un falante galego, a excepción das posibles interferencias e dialectalismos, de todos os xeitos pouco frecuentes na escrita e inexistentes na autotradución de Manuel Rivas.

Os demostrativos poden presentar variantes dialectais, especialmente na zona de Ourense, como iste ou aquil no canto de este ou aquel, mentres que os posesivos poden aparecer, neste caso debido a unha clara interferencia do castelán, sen o artigo anteposto. Aquí vemos un exemplo da correcta utilización do posesivo:

«A súa nai paríraa na cadea» [167]

«acompasa a súa necesaria rutina á imaxinación da terra.» [156]

No sentido inverso, podemos atopar unha interferencia do galego no uso dos posesivos, cando estes se manteñen mesmo sen ser necesarios, como ocorre na autotradución dos casos anteriores:

«Su madre la había parido en la cárcel» [226]

«acompasa su rutina necesaria a la imaginación de la tierra.» [233]

Por último, o artigo tampouco supón grandes dificultades, agás o uso do dialectalismo unhos ou do artigo masculino diante de substantivos que comezan por a tónica (solución que non existe en galego normativo).

\section{Pronome}

Como afirma Graña Núñez (1993: 63-67), a colocación dos pronomes persoais átonos é un dos aspectos máis problemáticos da lingua galega e resulta un bo indicador do dominio lingüístico dun falante. Así, resulta evidente a calidade da redacción de Manuel Rivas ao constatar a ausencia de erros referentes aos pronomes, tanto en galego como en castelán.

Non obstante, este non é o único problema que presentan os pronomes. Respecto á forma, poden aparecer variantes dialectais (il no canto de el), erros no uso de lle e lles e das súas contraccións co artigo determinado ou crases, ao apareceren xuntas dúas vogais iguais (a final do verbo e a inicial do pronome): 
«non lle queda máis remedio que lerllo.» [130]

«no le queda más remedio que leerlo.» [232]

(aquí vemos que o cambio no pronome, xustificado ou non, altera o sentido da oración)

Por outra banda, ás veces o uso tampouco resulta sinxelo, polo que se producen interferencias do castelán como a confusión entre o pronome de dativo e de acusativo (te e che); o calco nas combinacións do pronome se con lle/lles e $o / a / o s / a s$, que resulta moi forzado en galego; e o uso do se reflexivo con verbos galegos non reflexivos, con verbos de movemento ou cando xa hai outro obxecto directo na oración, xa que resulta redundante e pouco natural en galego, así como o seu uso con verbos con diferentes matices segundo sexan reflexivos ou non. A continuación, vemos algúns exemplos de verbos non reflexivos en galego que si o son en castelán:

«O abouxante silencio internacional sobre a guerra de Chechenia rachou.» [130]

«El estruendoso silencio internacional sobre la guerra de Chechenia se rompió.» [231]

«E cando lle falaron de quedar» [166]

«Y cuando le hablaron de quedarse» [226]

No tocante á colocación, é un aspecto bastante problemático onde abondan as interferencias do castelán (anteposición do pronome nos casos en que debe ir posposto) e as ultracorreccións (posposición sistemática do pronome sen ter en conta as excepcións á regra xeral). Algúns exemplos correctos do autor son:

«volvíase cara ao pai e dicíalle» [165]

«se volvía hacia su padre y decía» [224]

«ata que ao corso lle deu a arroutada charramangueira» [159]

«hasta que al corso le dio la vena hortera» [237]

\section{Preposición, conxunción e adverbio}

As categorías gramaticais invariables non adoitan provocar grandes confusións nos falantes debido, precisamente, á ausencia de variación das súas formas. Mencionaremos unicamente cuestións semánticas e sintácticas que, unha vez máis, son só posibles erros para os que non atopamos exemplos prácticos na obra analizada.

En primeiro lugar, as preposicións $a$, de, en e con poden non aparecer contraídas cos determinantes, especialmente nos sectores menos galeguizados que reciben, en maior medida, interferencias do castelán coma esta. Malia que neste caso sería un erro, xa que en galego é obrigatorio facer estas contraccións, non o sería no caso dos pronomes, cos que non poden contraer as preposicións, a excepción da preposición de:

«os enclaves míticos na paisaxe da sociedade do benestar» [140]

«Un deles é o escritor norteamericano Frank Baum» [149]

Outra posible interferencia do castelán no galego é frecuente no uso da preposición $a$ para introducir un obxecto directo, moi recorrente en castelán pero incorrecto en galego:

«que poñen $a$ xente aínda máis nerviosa» [128]

«que ponen a la gente todavía más nerviosa» [229]

Por outra banda, as conxuncións e os adverbios non presentan conflitos formais, unicamente existen algunhas incorreccións semánticas en adverbios como sempre e decote, ou 
pragmáticas e de estilo nas conxuncións, que se manifestan no uso dun adverbio ou unha conxunción incorrectos dentro do contexto ou do estilo do texto no que se atopan.

\section{Número e xénero}

No caso das palabras que teñen un xénero diferente en galego e en castelán, compróbase que o autor ten un bo dominio do léxico en ambas as dúas linguas, xa que non incorre en erros deste tipo e cambia acertadamente o xénero galego polo castelán:

«Ninguén fotografará o seu derradeiro sorriso» [156]

«Nadie fotografiará su última sonrisa» [233]

«O catálogo, o valo publicitario,» [149]

«El catálogo, la valla publicitaria,» [216]

«O noso home aínda tivo a coraxe de reflexionar en público» [144]

«Nuestro hombre aún tuvo el coraje de reflexionar en público» [212]

Do mesmo xeito, utiliza un galego normativo no tocante á formación do plural, evitando utilizar variantes dialectais para os plurais das palabras rematadas en $-n$ ou $-l, \tan$ frecuentes na lingua oral e moitas veces debidos tamén á ultracorrección e ao afán diferencialista dos partidarios do lusismo, pero moi poucas veces xeradas por descoñecemento da gramática ou por presión do castelán:

«remexer non andeis das tendas de prensa» [129]

«O asunto das nacións pode chegar a ser moi aburrido.» [143]

\section{Interferencias}

Como xa dixemos ao analizar en cadanseu apartado os distintos tipos de palabras problemáticas (no referente á morfosintaxe) que poderiamos atopar ao traducir entre linguas tan próximas como o castelán e o galego, no caso do escritor coruñés Manuel Rivas non se dá ningunha das interferencias máis frecuentes entre falantes bilingües.

\section{Reordenación sintáctica}

Por último, vemos neste apartado algúns exemplos de construcións sintácticas que varían no texto galego e no castelán debido, probablemente, a melloras ou preferencias do autor:

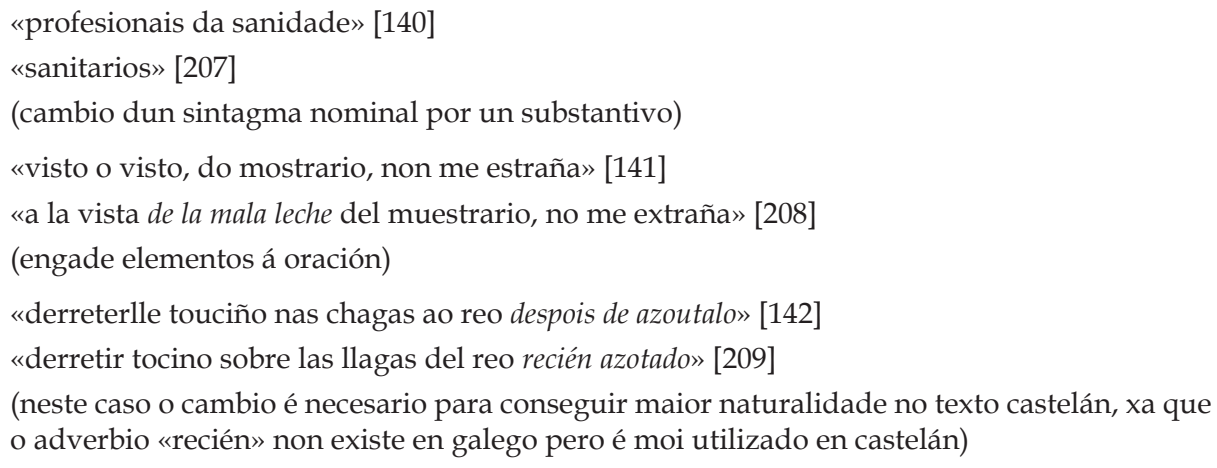


«entre eles xente que mesmo pasa por sabia» [145]

«incluso entre ellos, gente que pasa por sabia» [213]

(reformulación sintáctica)

\section{Aspectos léxico-semánticos}

Trataremos aquí dos falsos amigos, das interferencias, das ambigüidades e dos diversos elementos fraseolóxicos que se poden atopar ao longo do libro e que puideron constituír unha dificultade para o tradutor e conducilo a cometer algún debido ao complicado de saber onde se atopa a fronteira entre un par de linguas tan próximas.

\section{Falsos amigos}

No anaco do libro analizado non atopamos ningún exemplo de falsos amigos.

\section{Elementos fraseolóxicos}

As expresións feitas soen presentar dificultades xa que, en moitas ocasións, cómpre captar o sentido e facer unha nova reformulación sen poder ter en conta os elementos da unidade fraseolóxica orixinal. Así, por exemplo, na versión galega, aparece a expresión «un verme carpinteiro» [148] que Manuel Rivas traduciu por «aguafiestas» para o castelán. Na mesma páxina, podemos atopar tamén «volverás coma un farrapo», onde Rivas optou por manter unha expresión castelá coa mesma forma: «volverás echo polvo». Outro exemplo é «bótalles un sermón con avemaría» por «les saca los colores», aínda que nesta ocasión cámbianse totalmente as estruturas; ou outro máis doado como «levar á boca», do que se pode mesmo facer unha tradución palabra por palabra: «llevar a la boca».

\section{Ambigüidades}

Por outra banda, e continuando co anterior, tamén hai palabras que quedan máis neutras, máis vulgares, ou ben que manteñen o mesmo sentido pero que son totalmente diferentes, ou que nunha das linguas teñen máis dunha acepción. Por exemplo: «e sen aia» [129], que o escritor traduciu por «y sin niñera» [229]; neste caso, o termo «aia» é máis formal que «niñera» en castelán.

Outro termo que perde significado é o de «panasco» [156] que se traduce por «césped» [233]. O galego é unha lingua que ten moitos termos para denominar ás terras e ás herbas, dada a vinculación do mundo galego ao agro. Isto non ocorre co castelán, polo que «panasco» (segundo o Diccionario de Xerais: «terreo no monte onde medra a herba de forma espontánea ou herba dura que nace nos prados que non regan») non é o mesmo que «césped» (que o Diccionario María Moliner define como «hierba corta y espesa que cubre el suelo, crecida naturalmente, o criada artificialmente en un parque o jardín»). Outra diferenza entre galego e español é o feito de que en español só existe «último» cando en galego existe «último» (que pode ter unha continuación) e «derradeiro» (último elemento dunha serie que non pode ter máis elementos), matiz que ben soubo diferenciar Manuel Rivas na súa tradución de «o seu derradeiro sorriso, a súa derradeira rosa». Outro cambio de expresións é o de «merda de», máis coloquial que «quítame las pajas de»; «mexamorniño» por «tiquismiquis», «cuadrillero» por «pandillero», etc. Ademais, na tradución de «cheiro» por «olor» pérdese intensidade, xa que «cheiro» reflicte a idea, 
na meirande parte das veces, dun mal olor e «olor» en castelán pode ser bo olor ou malo, polo que xulgamos que sería mellor traducilo por «peste». Así e todo, no caso de «recendo», Rivas si que mantivo o sentido de bo olor ao traducir esta palabra por «aroma». Con respecto ás palabras con máis dun significado nunha das linguas, temos o exemplo de «peixe» [160], que en galego só se refire ao animal capturado e preparado para consumilo e por iso se traduciu por «pescado» e non por «pez», que en castelán unicamente fai referencia ao animal.

\section{Interferencias}

As interferencias atopadas nesta publicación débense a que na data de aparición aínda non estaba en vigor a nova normativa de 2003. Así, as palabras «espacio», «succionada», «gracias» e «servicio» non serían correctas en galego e habería que cambialas por «espazo», «sucionada», «grazas» e «servizo». Por outra banda, Manuel Rivas non comete ningunha interferencia de moita importancia e precisamos o bo uso dos tempos verbais do pasado na súa tradución: «chegouse» [128] por «se ha llegado» [229] ou «lles chapodou» [160] por «ha rebanado a» [240].

Tamén hai que destacar a construción dos verbos con OD en galego, que non levan preposición mentres que en castelán si («poñen a xente» [128] por «ponen a la gente» [229]) ou os cambios no referente aos verbos reflexivos («encasquetou» [160] por «se calzó» [240] ou «quedar» por «quedarse»).

\section{Aspectos estilístico-discursivos}

Estudamos aquí os procedementos que Rivas levou a cabo para a autotradución da súa obra. Os procedementos técnicos de tradución que se tomaron como referencia son os trece establecidos por Heloísa Gonçalves Barbosa (1990) como proposta á pregunta de «¿como traducir?». Na obra Muller no baño e na súa tradución Mujer en el baño, non aparecen os 13 procedementos pero aínda así explicarémolos todos.

\section{Tradución palabra por palabra}

O primeiro destes procedementos é a tradución palabra por palabra, moi presente na obra por tratarmos cun par de linguas moi próximas, e onde se substitúe un segmento textual por outro mantendo as mesmas categorías gramaticais, a mesma orde sintáctica e un vocabulario case idéntico. Algúns exemplos atópanse en «A señora Razón Crítica é ascéptica e práctica» [148] traducido por «La señora Razón Crítica es ascéptica y práctica» [214], «Eran máis eróticos os manequíns ortopédicos» [150] por «Eran más eróticos los maniquís ortopédicos» [216], «Hoxe en día» [165] por «Hoy en día» [224], «Escribir é tamén envexar» [157] por «Escribir es también envidiar» [234], etc.

\section{Tradución literal}

Este segundo procedemento consiste en manter o significado pero adecuando o escrito ás normas gramaticais da lingua de chegada: «¿e logo...?» [148] por «¿Y qué me dices de...?» [214], «hase encargar de recordarnos» [148] por «nos recordará que» [214], «dos nosos días» [165] por «de nuestros días» [224], «e mais a súa circunstancia» [165] por «y su circunstancia» [224], «mesmo hai sitios que» [128] por «hay sitios incluso» [229], etc. 


\section{Transposición}

Este procedemento supón un cambio de categoría gramatical dos elementos que se deben traducir, como é o caso de «despois de azoutalo» [142] por «recién azotado» [209] ou «que levou» [142] por «llevados» [209].

\section{Modulación}

Coa modulación cámbiase o punto de vista do segmento que hai que traducir. Nesta obra non hai moitas modulacións, pero pódese observar este procedemento no caso de «ata que te rozan» [129] por «hasta que las rozas» [229].

\section{Equivalencia}

A equivalencia aplícase normalmente ás expresións idiomáticas, aos refráns, etc., onde o que hai que traducir é o sentido, por non funcionar unha tradución literal. É o caso de «valvirón ao estaribel» [165] por «revolcón al tinglado» [224] ou, nas mesmas páxinas, «bótalles un sermón con avemaría» por «les saca los colores»; «titulares que nin cagados» [128] por «servían a huevo los titulares» [229], «tocar os perendengues» [129] por «tocar las narices» [229], «a gaita para o gaiteiro» [130] por «zapatero a tus zapatos» [231], «chapodarlle os tomatiños» [156] por «podarle los huevos» [233], etc.

\section{Omisión / explanación}

A omisión e a explicitación non están moi presentes no texto ao atoparnos entre culturas moi próximas case coa mesma realidade. Así e todo, podemos ver unha explicitación en «visto o visto, do mostrario» [141] por «a la vista de la mala leche del muestrario» [208]; ou a omisión na versión española de «de vez» [141]. Na páxina 142, «pringao é o que» por «pringado el que» [209] onde se omite o verbo. Ademais, hai moitos casos nos que as omisións teñen que ver coas normas gramaticais da propia lingua, como é o caso de «das pombas» [142] por «de palomas» [210] ou o caso dos verbos con OD españois que en galego non levan nunca preposición coma en «poñen a xente» [128] por «ponen a la gente» [229]. Un caso de explicitación é o de «que era como llamaban los...» [231] que na versión galega non aparece. Outro caso de omisión é o de «colle e papa» [130] por «se zampa» [231], etc.

\section{Compensación}

A compensación ten que ver con procurar o mesmo efecto estilístico nos dous textos. Isto apréciase no conxunto dos dous libros e máis adiante adicaremos un apartado a este tema.

\section{Reconstrución dos períodos}

A reconstrución de períodos consiste en reagrupar ou dividir dúas ou máis frases. Isto ocorre, por exemplo, no caso de «irreal. E hainos» [128] por «...y los hay que...» [229] ou en «¿E logo pensan...?» [130] por «Pero, ¿creen...?» [231]. 


\section{Mellora}

O seguinte procedemento que sinala Gonçalves Barbosa é o de mellorías, que consiste en non repetir na tradución erros cometidos no texto de partida, como por exemplo «ou» [143] por «y» [211].

\section{Transferencia}

O décimo procedemento é o dos estranxeirimos: pódense adaptar á lingua de chegada (aclimatación), explicitarse cunha nota, ou ben poden xa estar totalmente admitidos na lingua de chegada. No caso de «dexota, disxokey» [141] por «dejota, discjockey» [208], o tradutor fixo unha aclimatación á fonética tanto galega coma castelá. Por outra banda, «derby» é unha voz inglesa que está totalmente admitida nas dúas linguas, ao igual que «Waterpolo». En canto ao termo «pijo» que aparece na obra, Manuel Rivas non o traduciu en ningún momento xa que todos os galegos entenden o que se quere dicir con esa palabra, polo que constitúe un estranxeirismo do español que comeza a dicirse tamén en galego.

\section{Explicación}

A explicación consiste en substituír un estranxeirismo pola súa explicación sen nomear a palabra. Neste libro non atopamos ningún caso deste procedemento.

\section{Calco}

O calco consiste en traducir literalmente sintagmas e tan só atopamos un exemplo nesta obra, xa que a meirande parte destes segmentos se traducen de forma literal ou palabra por palabra. O exemplo de calco é o que figura na páxina 215 castelá e na súa correspondente galega, 149, ó ler «codicia» cando, en realidade, debería ser «cobiza» en galego.

\section{Adaptación}

E, por último, a adaptación, que se realiza cando o texto de partida ten unha realidade que non existe na cultura de chegada. Entre galego e castelán non hai moito espazo para facer este procedemento pero, non obstante, Rivas emprega «raxo» na páxina 148 que traduce por «solomillo» na páxina 214 cando non é o mesmo pero o «raxo» non é coñecido con ese nome no resto de España, onde é máis típico xantar un «solomillo».

\section{Aspectos toponímicos e antroponímicos}

\section{Aspectos toponímicos}

Se ben nos capítulos analizados apareceron un bo número de topónimos, estes non foron tratados da mesma maneira polo autor en galego que en castelán. Baseándonos na obra de Benigno Fernández Salgado Os xentilicios e os topónimos do mundo (1990), imos analizar e explicar as razóns destes cambios.

Hai unha serie de topónimos españois que no orixinal galego se conservan igual, posto que en galego a súa grafía é a mesma e non precisan ninguna adaptación, como é o caso de «España» [144, 214], «Barcelona» [161, 239] e «Lima» [166, 226]. Dentro dos topónimos españois tamén están os que se adaptan ás normas ortográficas galegas, como 
«Argentina» [212], que pasa a ser «Arxentina» [144]; e os que se traducen, como «Buenos Aires» [212] e «Bos Aires» [144]. O autor fixo un uso correcto de todas estas estratexias de adaptación e conservación dos topónimos españois.

Tamén atopamos algúns topónimos que conservan a súa grafía orixinal tanto en galego como en castelán, porque polo seu uso relativamente recente consérvase o nome na lingua orixinal, ademais de que é unha das estratexias de tradución de topónimos que máis se acostuma utilizar. Como exemplo temos «Seattle» $[129,230]$, «Tasmania» [157, $234]$ e «Roma» [160, 238], que aparecen no idioma orixinal en ambas as dúas obras, como é o seu uso correcto segundo as normas.

Pola contra, outros topónimos estranxeiros adaptáronse á grafía castelá e posteriormente á galega, pois temos que destacar que os estudos sobre a tradución de topónimos á lingua galega son posteriores. Algúns destes topónimos que se adaptaron e aparecen nestes capítulos son «París» [130, 231], «Chechenia» [130, 231], «Londres» [140, 207], «Francia» $[144,212]$ e «Palestina» $[159,237]$. Dentro dos topónimos adaptados hai unha particularidade, pois dáse o caso de que algúns deles en castelán non se adaptaron pero en galego si. Estas diferenzas estriban sobre todo na acentuación, pois segundo Fernández Salgado hai que acentuar á galega sempre que cumpra. Algúns exemplos do texto son «Washington» [230], en castelán, e «Wáshington» [129], en galego; e «Oxford» [239], en castelán, e «Óxford» [161], en galego.

Tamén temos que incluír os topónimos estranxeiros que case sempre se traducen, como é o caso da cidade norteamericana New York, que en castelán sempre se traduce por «Nueva York» [230] e en galego por «Nova York» [129].

\section{Aspectos antroponímicos}

En canto aos nomes propios de persoa, o autor conserva o antropónimo orixinal en toda a obra salvo unha excepción, o que consideramos unha boa decisión pois, ademais de que se entenden, son de uso normal e non resultan estraños, xa que moitos corresponden a personaxes públicas coñecidas.

A excepción é «Napoleón» [159, 237], que escrito en francés é Napoléon, pero que se adaptou ás normas de acentuación españolas polo que o acento mudou do $e$ ao $o$; o autor seguiu esta convención na súa obra e fíxoo correctamente, pois en español e en galego escríbese así e o cambio de ortografía podería confundir ao lector.

Sinalamos agora algúns dos antropónimos que figuran na obra: «Brooklyn» [129, 229], que tamén é un topónimo, pero neste caso fai alusión ao nome dunha persoa; «Günter Grass» [231], que en galego está mal escrito (Günther Grass [130]), pero en castelán xa está corrixido; ou «a raíña/ reina Victoria» $[142,210]$.

\section{Aspectos culturais}

Os aspectos culturais constitúen unha parte moi importante dentro do ámbito da tradución e cómpre prestarlles especial atención xa que deles depende, en moitos casos, que a tradución acade ou non o obxectivo buscado. Deste xeito, deixar de explicar algún aspecto cultural pode supor unha falta de información importante que pode chegar a impedir que se comprenda o significado conxunto do texto en cuestión.

Toda tradución caracterízase por estar vinculada non só a unhas linguas concretas, senón tamén a unhas culturas determinadas. É por iso que, ademais de ter en conta as 
cuestións lingüísticas, tamén hai que reparar en todas aquelas que podan afectar á cultura dende e para a que se traduce. Malia a idea tan espallada de que traducir é un proceso que se realiza entre linguas, a realidade é un chisco máis diferente, pois traducir é unha actividade que se leva a cabo entre, polo menos, dúas culturas.

Se ben a lingua é un dos elementos máis importantes á hora de afrontar calquera tradución, non hai que esquecer que a cultura é un concepto ineludible que cómpre ter presente tanto ou máis que a propia lingua. En moitas ocasións, é a cultura a que guía un proceso tradutor aínda que, cando se trata de linguas e culturas próximas, fai que se lle dea menos valor do que ten en realidade. A relevancia dunha cultura vén dada polo feito de que, sen ela, o proceso de tradución sería imposible: non se pode traducir se se descoñece a cultura de partida ou de chegada. Así pois, tradúcese entre lingua e cultura, dous conceptos inseparables neste ámbito e que fan que a tradución sexa bilingüe e, ao mesmo tempo, bicultural, que conste duns parámetros lingüísticos e outros extratextuais que tamén se deben ter en conta.

No que se refire ás obras obxecto de análise, as referencias culturais non presentan grandes problemas e ningunha inflúe na comprensión do texto. Isto débese a que as linguas e culturas coas que estamos a tratar son moi próximas, o que fai que as diverxencias sexan practicamente inexistentes. Referencias do tipo «País de Oz» $[149,215]$ ou «Lei do Desexo» [149]/ «Ley del Deseo» [215] non supoñen grandes problemas á hora de comprender o texto e simplemente poñen de manifesto obras de sobra coñecidas polo público español e galego e que levan a nosa memoria ata as aventuras do Mago de Oz ou que nos fan lembrar a película de Pedro Almodóvar.

Termos como «Santa Compaña», «meigas» ou «palilleiras», fortemente ligados á cultura galega, non sempre son (re)coñecidos máis aló das fronteiras da nosa comunidade, polo que a falta de explicitación ao referirnos a eles suporía tamén unha falta importante de información que non deixaría acadar o obxectivo pretendido con esa tradución.

\section{Aspectos estéticos}

A autotradución, como ben dixemos anteriormente, ofrece ao autor a facilidade de modificar o texto orixinal de cara á tradución, pois é a súa propia obra a que está sendo obxecto de manipulación. Deste xeito, ten a opción de mellorar o documento orixinal ou de modificalo dependendo do sentido concreto que desexe transmitir. Pode que un autotradutor non conte coas competencias tradutoras dun profesional nesta materia, pero ten a vantaxe de que ninguén mellor ca el coñece o texto que se está a traducir, polo que ninguén máis poderá determinar coa mesma precisión cada detalle que se está a expresar e cada sentido que ten o texto orixinal. Ademais, autotraducir unha obra ten outra vantaxe engadida: supón unha nova revisión da obra orixinal, o que permite corrixir erros que se puideron ter cometido sen que o autor se decatase. Isto explica que as autotraducións non sexan sempre iguais ao orixinal e que poda haber cambios, pois o autor ten unha nova oportunidade para reparar contrasentidos, erros de significado ou, simplemente, para facer cambios coa intención de mellorar esteticamente a nova obra.

Así e todo, o resultado global da autotradución podería semellar, nunha primeira ollada, un texto fidedigno e literal, no sentido estrito da expresión, ao texto orixinal. Isto indicaría a vontade expresa de manter non só o sentido, mais tamén a forma do documento de partida. Agora ben, no caso de atopar unha dificultade de tradución que requira dunha reformulación estética, o autotradutor tende a tomar unha solución que posúa unha 
fluidez de seu no texto traducido, o que implica en moitos casos adoptar medidas que valoren a repercusión no receptor dun determinado segmento textual. É precisamente neste tipo de contextos nos que o autor opta por realizar unha amplificación, unha redución ou ben, de ser necesario, unha substitución.

\section{Amplificacións}

Na maior parte dos exemplos que localizamos neste texto, as amplificacións correspóndense coa necesidade de adaptarse á estrutura morfosintáctica e expresiva máis idiomática no texto receptor. Deste xeito, atopamos o caso de «visto o visto do mostrario» por «a la vista de la mala leche del muestrario» $[140,207]$; «Ø» por «algunas» $[143,211]$; e «Ø» por «que era como llamaban los» $[130,231]$. Certas amplificacións débense a matices de significado, cando cómpre engadir unha pequena información; por exemplo: «merda de» por «quítame las pajas de», que ademais presenta unha atenuación na súa coloquialidade.

\section{Reducións}

Na cara oposta da moeda atópanse as reducións e certos casos tamén se deben case sempre a modificacións na estrutura natural do discurso, como «pringao é o que» por «pringao el que» $[141,208]$. Noutros, simplemente, son o resultado dunha opción de tradución tomada polo autotradutor: "profesionais da sanidade» por «sanitarios» [140, 207], «de vez» por «Ø» $[141,208]$, «o feito de escribir» por «el escribir» $[156,233]$ e «meritoria abondo, fora a ialma» por «harto meritoria». É de destacar, neste último caso, o feito de que se produce unha notable perda na carga semántica da expresión en galego. En contrapartida, no seguinte exemplo, a redución non só mantén a carga semántica, senón que tamén se adapta perfectamente á oralidade da expresión en español: «colle e papa» por «se zampa» $[130,231]$.

Dentro do ámbito das reducións, cómpre dicir que na comparación das dúas obras, ademais de omisións en oracións ou pequenos segmentos lingüísticos, tamén comprobamos que se eliminan capítulos na obra castelá e que, ademais, en ocasións modifícase a orde de colocación dos mesmos.

\section{Substitucións}

As substitucións prodúcense, na súa maior parte, naqueles casos nos que unha realidade ou referente non presenta unha correspondencia formal, sexa de tipo parcial ou total, para o par de linguas no que se traduce. Deste xeito, moitas substitucións son parellas ao procedemento seguido no caso de aplicar unha equivalencia, no que se prima o aspecto funcional, e así o atopamos nos seguintes segmentos fraseolóxicos: «un verme carpinteiro» por «aguafiestas» $[148,214]$, «coma un farrapo» por «hecho polvo» $[149,215]$, «bótalles un sermón con avemaría» por «saca los colores» $[165,224]$, «servían a huevo los titulares» no canto de «titulares que nin cagados» [128, 229], «tocar os perendengues» por «tocar las narices» $[129,229]$, «a gaita para o gaiteiro» por «zapatero a tus zapatos» $[130,231]$, «que mira para o punteiro» por «que se mira para los zapatos» [130, 231], «chapodarlle os tomatiños» por «podarle los huevos» [156, 233], «tiquismiquis» por «mexamorniño» $[157,234]$, «raxo» por «solomillo» $[149,214]$ e «pelmazo» no canto de «prosma» $[160,238]$. Ora ben, as substitucións poden diferenciarse das equivalencias 
no feito de que o resultado obtido non é semanticamente tan coincidente como cabería esperar. Moitas veces, esta separación débese a unha opción de tradución, xustificable en certos casos, claramente accesoria noutros, coma en «guano» por «excrementos» [142, $210]$ e «terras» por «parajes» $[143,211]$.

Entre as substitucións que se fan con finalidade estética, podemos mencionar aquelas nas que unha preposición é substituída por outra sen razón aparente, simplemente por considerar, talvez, que esa era a máis adecuada ou atendendo a razóns que teñen que ver co gusto do autor. É o caso de «cuidar a su hijo Brooklyn» que foi substituída por «coidar do seu fillo Brooklyn» na versión galega $[129,229]$. Outros exemplos poden ser «en una propiedad» por «dunha propiedade» $[129,230]$ ou, nas mesmas páxinas respectivamente, «en grandes almacenes» e «nos grandes almacéns», nos que se engade o artigo na versión galega sen ningunha finalidade aparente, aínda que serve para concretar máis a que grandes almacéns se refire, posto que o artigo determinado fai que o nome ao que acompaña sexa máis coñecido.

Na páxina 231 da versión española, comprobamos como o pronome demostrativo «esta» vén na versión galega como o demostrativo «esa» [130]. O sentido permanece sen ser alterado e a única diferenza responde aos matices que caracterizan aos demostrativos en español e galego, é dicir, diferenzas de distancia.

Finalmente, cómpre destacar que os aspectos estéticos que xorden da comparación destas obras non se reduce tan só ás amplificacións, reducións e substitucións, senón que tamén atopamos outros pequenos matices. Tal é o caso da alteración da colocación do pronome en «su rutina necesaria» por «a súa necesaria rutina» $[156,233]$ e «desafíos públicos» por «públicas retesías». A anteposición do adxectivo cumpre cun valor estético de énfase bastante relevante na redacción, tanto en galego como en español; a súa posposición supón unha lixeira perda no valor estético do discurso. Tamén atopamos un caso de perda de carga semántica con función estética no caso de «su última sonrisa, su última rosa» por «o seu derradeiro sorriso, a súa última rosa», na que que o autor non propón ningún tipo de compensación. Para rematar con este punto, un último exemplo no que se refire á adecuación estética que, neste caso si, o autor soubo solventar con bastante facilidade: «Arca de No Es» por «Arca de No(n) É».

\section{Conclusións}

O resultado deste traballo pode ofrecer, de xeito máis claro, as ideas que xa avanzabamos ao comezo do mesmo. Abordar o comentario crítico dunha tradución non é tarefa sinxela, sobre todo de coñecérense en primeira persoa as dificultades que debe manexar todo tradutor.

Nunha primeira impresión, poderíase esperar que a faceta de autor primase sobre a do tradutor e, en consecuencia, que se producise un afastamento ostensible do texto de partida e, así, unha recreación artística do mesmo. Lonxe de caer na pantasma das belles infidèles, o certo é que Manuel Rivas adáptase, na medida do posible e cunha literalidade case inesperada, ao texto orixinal, deixando a substitución de elementos que provocan as diferenzas máis notables para cando supoñen unha traba para a comprensión da tradución. En suma, poucos son os casos nos que o autor se deixa levar pola súa faceta de creador e acostuman referirse aos aspectos estéticos ou, simplemente, ás técnicas discursivas propias dunha redacción idiomática na lingua de chegada. 
Ademais diso, pódese apreciar unha calidade como escritor e como falante bilingüe que lle permite elaborar un traballo libre de interferencias, sexa do galego ao castelán ou viceversa, creando un texto que resulta natural e facilmente comprensible e onde se comproba un profundo coñecemento da morfoloxía tanto galega como castelá. Ben se podería afirmar, á luz da análise, que o feito de posuír unha comprensión presumiblemente perfecta do texto de partida garantiza o éxito no momento de evitar interferencias ou erros de significado. $\mathrm{O}$ autor adoita atopar expresións equivalentes para os elementos fraseolóxicos e mantén tanto o carácter funcional como o semántico de moitas delas. As pequenas diverxencias criticables débense, polo xeral, a lagoas terminolóxicas nunha ou noutra direccionalidade; así, o autor pode precisar «pescado» no canto de «peixe» no texto castelán pero desdebuxa outros termos como «panasco», traducido por «césped».

$\mathrm{O}$ feito de que a autotradución sexa un proceso entre pares de linguas próximas está moi presente nas decisións tomadas durante o mesmo. A isto débese, por exemplo, a presenza xeral da tradución literal, cando non palabra por palabra, que facilita a maior semellanza posible ao texto de partida. En gran medida, as opcións elixidas durante a tradución achéganse á vontade de manter o carácter idiomático da mesma.

Para rematar, a proximidade de linguas facilita unha maior intercomprensibilidade dos referentes e, polo tanto, unha menor manipulación destes elementos no proceso de tradución, así como uns procedementos moi similares ao proceso de creación e que non precisan de grandes modificacións para ser expresados na lingua de chegada.

\section{Bibliografía}

Blanco Rodríguez, Luisa (1988), «La galleguidad de Álvaro Cunqueiro en su obra en castellano: Galleguismos léxicos y sintácticos», Revista de Estudios Provinciais 4. Pontevedra.

DAsilva, Xosé Manuel (2009), «Autotraducirse en Galicia: ¿bilingüismo o diglosia?», Quaderns: revista de traducciò 16, 143-156.

FERNÁNDEZ ConTe, Natalio (2001), Apuntes de acentuación, sintaxis, normas y estilo, Madrid: Anaya.

Fernández Salgado, Benigno (1990), Os Xentilicios e os topónimos do mundo, Santiago de Compostela: Dirección Xeral de Política Linguística.

Gonçalves Barbosa, Heloísa (1990), Procedimentos técnicos da tradução: uma nova proposta, Campiñas: Pontes.

GraÑa NúÑEZ, Xosé (1993), Vacilacións, interferencias e outros «pecados» da lingua galega, Vigo: Ir Indo.

RodRíGUEZ VEGA, Rexina (1999), «A tendencia á hipercorrección do escritor bilingüe. O caso das autotraduccións ó castelán de Álvaro Cunqueiro», in: Álvarez, Rosario - Vilavedra, Dolores (eds.), Cinguidos por unha arela común: Homenaxe ó profesor Xesús Alonso Montero. Tomo II: Literatura, Santiago de Compostela: Universidade, Servicio de Publicacións e Intercambio Científico, 1355-1372.

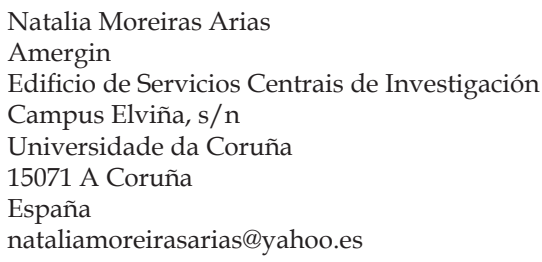

